\title{
Optimization of resource use in the formation of a network interaction model
}

\author{
Andrey Plakhin*, Maxim Kocheryan, Elena Davydova, and Natalia Shuraleva ${ }^{1}$ \\ Ural State University of Economics, 620144 Ekaterinburg, Russia
}

\begin{abstract}
The article is based on the research materials of the network interaction of universities in the context of physical culture and sports activity. The research is based on the methodology of network theory and the resource approach in the strategic management of organizations. The results of the study show that the formation of a network model can significantly increase the coverage of the population with projects of physical culture and sports activity using already existing resources. The results obtained indicate the effectiveness of strategies for networking organizations.
\end{abstract}

\section{Introduction}

The formation of a network strategy for managing a university is a priority task at the present stage of development of the education system of the Russian Federation. Its use is based on resource, relational and network theories, the provisions of which are adapted for the university as an object of strategic management in the works of A.A. Gres'ko, M.S. Rakhmanov, K.S. Solodukhin [1], K.S. Eleneva, Yu.Ya. Yeleneva [2], V.N. Lupanov [3]. Network strategic management in general involves the use of various integrative forms in order to form and effectively use the infrastructural, intellectual and resource potential of network participants [4].

These multifaceted connections are explained within the framework of the concept of "network", which is a set of individual subjects of physical culture and sports activity and multidirectional connections between them. In the work of M. Castells [5] it is noted that in the context of the theory of networks, three key terms are used: network formation or networking, networks and network structures. Networking is a general term for activity, as a result of which connections are created between people and organizations through regular meetings, conferences, new communication technologies. Networks are formed when connections between organizations or individuals are formalized, i.e. become regular and subordinate to the principle of satisfying mutual interests. Network structures arise when the activity of separately acting network elements is no longer sufficient. Keast R. et al. [6] noted that network structures arise when the actors participating in the network realize that they are only small fragments of the big picture. Network structures may require independent actions of individual members, but at the same time, network members, when they take on complex tasks that are beyond the capacity of independently operating

\footnotetext{
*Corresponding author: apla@usue.ru
} 
organizations, are transformed into a new whole. Moreover, as noted in W. Mastenbrook's book [7], people depend on each other and have, at the same time, their own interests ... in a certain sense, we could even talk about a coalition of divergent interests.

At the same time, the subjects within the network organization of physical culture and sports activity in Russia have their own hierarchical characteristics [8]. So at the primary level, professional and amateur teams are distinguished at educational organizations and enterprises whose activities are related to physical culture and sports, amateur physical culture and sports teams, sports schools, sports clubs and sections.

The subjects of the primary level are the basis for the subjects of the second level of the hierarchy, whose activities are related to the issues of methodological, coordination and financial support of the primary level. The subjects of the second level of the hierarchy include sports associations, sports leagues and sports confederations.

On the basis of the subunits representing the primary public organizations of physical culture and sports in the Russian Federation, larger organizations are formed, designed to improve the efficiency, organizational and methodological or commercial leadership of the field of activity that unites these people. In the Russian Federation, such public organizations are: sports organizations, physical culture and sports societies, sports associations, sports federations, sports leagues, sports confederations, sports unions.

It is quite obvious that effective network strategies make it possible to resolve issues of coordination of activities, to overcome the resource constraints of individual universities through the formation of partnerships, unions, and associations. In turn, the theory of strategic management considers networks as a way of organizing the activities of relatively independent subjects, which in the framework of the subject of this study are institutions of higher education. Subjects remain independent while pooling resources and forming stable relationships with respect to objects of interaction. And for the physical culture and sports activities of the university, the objects are joint projects, including both educational activities and socially significant events with the participation of universities.

\section{Methods}

In the context of the research, the following conceptual model of the formation of a network strategy for the interaction of physical culture and sports activities of a university within the framework of the project approach is presented in Figure 1.

The implementation of the conceptual model essentially corresponds to the solution of a large-scale optimization task, where the target function is to maximize the number of participants included in the projects of physical culture and sports activity, and resource constraints provide for the analysis of the following:

- $\quad$ Sport facilities;

- Sport equipment;

- Financial resources;

- Staff.

According to the proposed model, it is necessary to analyze the totality of projects of physical culture and sports activities of the university, which are planned to be implemented in the coming period. The main factors of the analysis are determined by the needs for the resources involved for the implementation of these projects. At the same time, the possibilities of external counterparties - potential participants in network interaction are being studied, their characteristics and resource potential are determined, which can be used in the implementation of joint projects. 


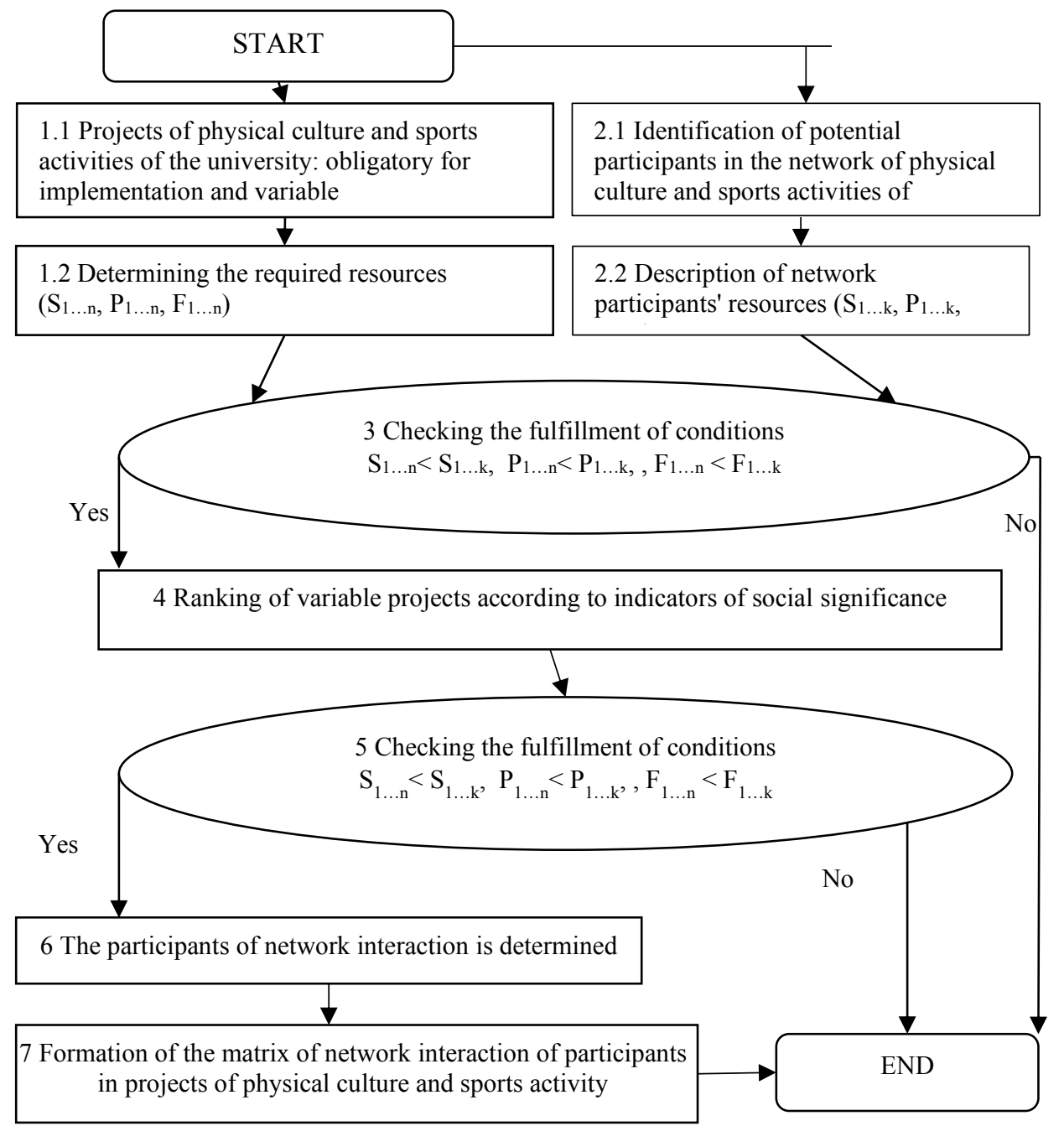

Fig. 1. Conceptual model of network management of physical culture and sports activities of the university within the framework of the project approach

Next, you should correlate the resources available to the university and the resources of partners. If it turns out that there are not enough resources, but at the same time there are network actors with these resources in a large (sufficient) volume, then you can proceed to the next step, which should assess the social significance of the projects planned for implementation. After ordering according to the degree of importance, it is possible to form a matrix of network interaction of the participants of the planned projects.

\section{Results}

On the basis of the proposed algorithm, a complex of projects of physical culture and sports activity of universities of the Sverdlovsk region was formed. Table 1 presents the characteristics of the projects obtained as a result of the implementation of stages 1.1 and 1.2 of the methodology. 
Table 1. The list of projects of physical culture and sports activities implemented in the territory of the Sverdlovsk region and their resource requirements.

\begin{tabular}{|c|c|c|c|c|c|c|}
\hline \multirow{2}{*}{\multicolumn{3}{|c|}{\begin{tabular}{|c|} 
Name of projects of physical culture and sports \\
activities of universities of the Sverdlovsk region
\end{tabular}}} & \multicolumn{4}{|c|}{ Resource requirements } \\
\hline & & & \multirow{2}{*}{$\begin{array}{c}\begin{array}{c}\text { Sports } \\
\text { facilities }\end{array} \\
4000\end{array}$} & \multirow{2}{*}{$\begin{array}{c}\begin{array}{c}\text { Sports } \\
\text { equipment }\end{array} \\
4000\end{array}$} & \multirow{2}{*}{$\begin{array}{c}\begin{array}{c}\text { Financial } \\
\text { resources }\end{array} \\
4160\end{array}$} & \multirow{2}{*}{$\begin{array}{l}\text { Staff } \\
7644\end{array}$} \\
\hline \multirow{14}{*}{$\begin{array}{l}\frac{0}{0} \\
. \frac{0}{0} \\
0 \\
0 \\
0 \\
0 \\
0 \\
0.00 \\
.00 \\
0 \\
0\end{array}$} & $\begin{array}{c}\text { Basic professional } \\
\text { educational programs } \\
\text { № } 1-10 \\
\end{array}$ & $\begin{array}{l}\text { FSBEI HE "Ural State } \\
\text { University of Economics" }\end{array}$ & & & & \\
\hline & $\begin{array}{l}\text { Basic professional } \\
\text { educational programs } \\
\quad № 1-3\end{array}$ & $\begin{array}{l}\text { ANO HE "Humanitarian } \\
\text { University" }\end{array}$ & 408 & 408 & 2104 & 2489 \\
\hline & $\begin{array}{l}\text { Basic professional } \\
\text { educational programs } \\
\text { № } 1-15\end{array}$ & $\begin{array}{l}\text { FSAEI HE "Russian State } \\
\text { Vocational Pedagogical } \\
\text { University" }\end{array}$ & 1437 & 1437 & 7840 & 6578 \\
\hline & $\begin{array}{c}\text { Basic professional } \\
\text { educational programs } \\
\text { № } 1-45\end{array}$ & $\begin{array}{l}\text { FSAEI HE "Ural Federal } \\
\text { University named after the } \\
\text { first President of Russia } \\
\text { B. N. Yeltsin" }\end{array}$ & 18058 & 18058 & 30880 & 19133 \\
\hline & $\begin{array}{l}\text { Basic professional } \\
\text { educational program } \\
\quad № 1\end{array}$ & $\begin{array}{l}\text { FSBEI HE "Yekaterinburg } \\
\text { State Theater Institute" }\end{array}$ & 71 & 71 & 1232 & 1213 \\
\hline & $\begin{array}{l}\text { Basic professional } \\
\text { educational program } \\
\text { № } 1 \\
\end{array}$ & $\begin{array}{l}\text { FSBEI HE "Ural State } \\
\text { Conservatory named after } \\
\text { M.P. Mussorgsky" }\end{array}$ & 149 & 149 & 1760 & 1240 \\
\hline & $\begin{array}{c}\text { Basic professional } \\
\text { educational programs } \\
\text { № 1-3 }\end{array}$ & $\begin{array}{l}\text { FSBEI HE "Ural State } \\
\text { Medical University } \\
\text { "Ministry of Health of the } \\
\text { Russian Federation }\end{array}$ & 829 & 829 & 4160 & 4178 \\
\hline & $\begin{array}{l}\text { Basic professional } \\
\text { educational programs } \\
\quad № 1-7\end{array}$ & $\begin{array}{l}\text { FSBEI HE "Ural State } \\
\text { Pedagogical University" }\end{array}$ & 2862 & 2862 & 5320 & 3867 \\
\hline & $\begin{array}{l}\text { Basic professional } \\
\text { educational programs } \\
\text { № 1-5 }\end{array}$ & $\begin{array}{l}\text { FSBEI HE "Ural State Law } \\
\text { University" }\end{array}$ & 1878 & 1878 & 5440 & 4000 \\
\hline & $\begin{array}{l}\text { Basic professional } \\
\text { educational programs } \\
\text { № } 1-5\end{array}$ & $\begin{array}{l}\text { FSBEI HE "Ural State } \\
\text { Agrarian University" }\end{array}$ & 608 & 608 & 1840 & 1333 \\
\hline & $\begin{array}{l}\text { Basic professional } \\
\text { educational programs } \\
\text { № } 1-3\end{array}$ & $\begin{array}{l}\text { FSBEI HE "Ural State } \\
\text { University of Architecture } \\
\text { and Art" }\end{array}$ & 106 & 106 & 1040 & 711 \\
\hline & $\begin{array}{l}\text { Basic professional } \\
\text { educational programs } \\
\text { № } 1-12\end{array}$ & $\begin{array}{l}\text { FSBEI HE "Ural State } \\
\text { Mining University" }\end{array}$ & 3713 & 3713 & 6800 & 6133 \\
\hline & $\begin{array}{c}\text { Basic professional } \\
\text { educational programs } \\
\text { № } 1-12 \\
\end{array}$ & $\begin{array}{l}\text { FSBEI HE "Ural State } \\
\text { Forest Engineering } \\
\text { University" } \\
\end{array}$ & 2983 & 2983 & 6800 & 5756 \\
\hline & $\begin{array}{l}\text { Basic professional } \\
\text { educational programs } \\
\quad \text { № } 1-7\end{array}$ & $\begin{array}{l}\text { FSBEI HE "Ural State } \\
\text { University of Railway } \\
\text { Transport" }\end{array}$ & 3249 & 3249 & 5320 & 5511 \\
\hline
\end{tabular}


Continuation of Table 1. The list of projects of physical culture and sports activities implemented in the territory of the Sverdlovsk region and their resource requirements.

\begin{tabular}{|c|c|c|c|c|c|}
\hline \multirow{21}{*}{$\begin{array}{l}\frac{n}{0} \\
\frac{0}{0} \\
0 \\
0 \\
\frac{0}{0} \\
\frac{\pi}{\pi} \\
\frac{\pi}{\pi}\end{array}$} & Military sports games among university students & 26 & 26 & 52 & 39 \\
\hline & All-Russian race "Ski track of Russia" & 12 & 12 & 24 & 18 \\
\hline & $\begin{array}{c}\text { All-Russian sambo team tournament among students } \\
\text { in memory of the USSR master of sports }\end{array}$ & 28 & 28 & 56 & 42 \\
\hline & Nation Cross & 12 & 12 & 24 & 18 \\
\hline & $\begin{array}{c}\text { Open championship of the Sverdlovsk region in } \\
\text { sambo wrestling among senior schoolchildren for the } \\
\text { "Cup of the Rector of Ural State University of } \\
\text { Economics" }\end{array}$ & 8 & 8 & 16 & 12 \\
\hline & Open badminton tournament & 24 & 24 & 48 & 36 \\
\hline & $\begin{array}{c}\text { Ural State University of Economics open rock } \\
\text { climbing tournament "LIGHTNING" among junior } \\
\text { schoolchildren }\end{array}$ & 12 & 12 & 24 & 18 \\
\hline & Championship of Yekaterinburg in rock climbing & 20 & 20 & 40 & 30 \\
\hline & $\begin{array}{c}\text { Championship of the Sverdlovsk region in rock } \\
\text { climbing }\end{array}$ & 12 & 12 & 24 & 18 \\
\hline & $\begin{array}{c}\text { Volleyball Championship of the Ural Federal District } \\
\text { (2nd stage of the All-Russian Universiade) }\end{array}$ & 26 & 26 & 52 & 39 \\
\hline & $\begin{array}{c}\text { Regional Championship of the Association of Student } \\
\text { Sports Clubs (chess, table tennis) }\end{array}$ & 20 & 20 & 40 & 30 \\
\hline & $\begin{array}{c}\text { Competition in Yekaterinburg in shooting from } \\
\text { pneumatic weapons " Ural State University of } \\
\text { Economics Open Tournament" }\end{array}$ & 12 & 12 & 24 & 18 \\
\hline & $\begin{array}{c}\text { Competition in shooting from pneumatic weapons } \\
\text { "Victory Day" }\end{array}$ & 12 & 12 & 24 & 18 \\
\hline & Spartakiad of Leninsky district & 12 & 12 & 24 & 18 \\
\hline & Student regatta & 12 & 12 & 24 & 18 \\
\hline & Universiade of the Sverdlovsk region & 54 & 54 & 108 & 81 \\
\hline & $\begin{array}{l}\text { "Ready for Labor and Defense" festival among } \\
\text { correctional schools }\end{array}$ & 24 & 24 & 48 & 36 \\
\hline & Fitness congress & 24 & 24 & 48 & 36 \\
\hline & $\begin{array}{c}\text { Championship of the Russian Student Sports Union } \\
\text { in climbing, speed }\end{array}$ & 24 & 24 & 48 & 36 \\
\hline & $\begin{array}{c}\text { Relay "For the prize of the newspaper Vecherniy } \\
\text { Yekaterinburg" }\end{array}$ & 8 & 8 & 16 & 12 \\
\hline & Relay race of Leninsky district & 24 & 24 & 48 & 36 \\
\hline
\end{tabular}

The next step is to characterize the resource capabilities of each university from the standpoint of potential network interaction in the context of projects of physical culture and sports activities in accordance with paragraphs 2.1 and 2.2 of the developed methodology. Information on resource capabilities is presented in table 2. 
Table 2. Resource characteristics of participants in network interaction

\begin{tabular}{|l|c|c|c|c|c|}
\hline \multicolumn{1}{|c|}{ University name } & Ani.N & $\begin{array}{c}\text { Availabilit } \\
\text { y of time } \\
\text { for the use } \\
\text { of sports } \\
\text { facilities, } \\
\text { hour } / \\
\text { year }\end{array}$ & $\begin{array}{c}\text { Availabil } \\
\text { ity of } \\
\text { ime for } \\
\text { the use } \\
\text { of } \\
\text { inventor } \\
\text { y, hour } / \\
\text { year }\end{array}$ & $\begin{array}{c}\text { Availability } \\
\text { of financial } \\
\text { resources, } \\
\text { thousand } \\
\text { rubles }\end{array}$ & $\begin{array}{c}\text { Time } \\
\text { available for } \\
\text { staff } \\
\text { participatio } \\
\text { n, hour } / \\
\text { year }\end{array}$ \\
\hline $\begin{array}{l}\text { FSBEI HE "Ural State University of } \\
\text { Economics" }\end{array}$ & 1 & 3620 & 3620 & 5200 & 8600 \\
\hline ANO HE "Humanitarian University" & 2 & 1230 & 1230 & 2630 & 3200 \\
\hline $\begin{array}{l}\text { FSAEI HE "Russian State Vocational } \\
\text { Pedagogical University" }\end{array}$ & 3 & 4456 & 4456 & 9800 & 7400 \\
\hline $\begin{array}{l}\text { FSAEI HE "Ural Federal University } \\
\text { named after the first President of Russia } \\
\text { B. N. Yeltsin" }\end{array}$ & 4 & 18660 & 18660 & 38600 & 24600 \\
\hline $\begin{array}{l}\text { FSBEI HE "Yekaterinburg State Theater } \\
\text { Institute" }\end{array}$ & 5 & 860 & 860 & 1760 & 1560 \\
\hline $\begin{array}{l}\text { FSBEI HE "Ural State Conservatory } \\
\text { named after M.P. Mussorgsky" }\end{array}$ & 6 & 900 & 900 & 2200 & 1860 \\
\hline $\begin{array}{l}\text { FSBEI HE "Ural State Medical } \\
\text { University "Ministry of Health of the } \\
\text { Russian Federation }\end{array}$ & 7 & 2500 & 2500 & 5200 & 4700 \\
\hline $\begin{array}{l}\text { FSBEI HE "Ural State Pedagogical } \\
\text { University" }\end{array}$ & 8 & 3700 & 3700 & 7600 & 5800 \\
\hline FSBEI HE "Ural State Law University" & 9 & 3400 & 3400 & 6800 & 4500 \\
\hline $\begin{array}{l}\text { FSBEI HE "Ural State Agrarian } \\
\text { University" }\end{array}$ & 10 & 1100 & 1100 & 2300 & 1500 \\
\hline $\begin{array}{l}\text { FSBEI HE "Ural State University of } \\
\text { Architecture and Art" }\end{array}$ & 11 & 640 & 640 & 1300 & 800 \\
\hline $\begin{array}{l}\text { FSBEI HE "Ural State Mining } \\
\text { University" }\end{array}$ & 12 & 5600 & 5600 & 8500 & 6900 \\
\hline $\begin{array}{l}\text { FSBEI HE "Ural State Forest } \\
\text { Engineering University" }\end{array}$ & 4500 & 4500 & 8500 & 7400 \\
\hline $\begin{array}{l}\text { FSBEI HE "Ural State University of } \\
\text { Railway Transport" }\end{array}$ & 14 & 4200 & 4200 & 7600 & 6200 \\
\hline & 55366 & 55366 & 107990 & 85020 \\
\hline
\end{tabular}

The analysis showed that the total time of possible use of sports infrastructure facilities and sports equipment of universities in the Sverdlovsk region is more than 55 thousand hours, the time of staff use is 85 thousand hours, and financial resources are estimated at more than 107 million rubles. Since these resources are unevenly distributed among universities, the optimization task, which is posed as part of the development of strategies for network interaction of universities, boils down to ensuring the most efficient use of resources, taking into account the preference of projects in terms of social indicators, as well as reaching the maximum possible number of participants. To solve this problem, we will consider the use of resources for the implementation, first of all, of projects of physical culture and sports activity that are obligatory for implementation in universities (point 3 of the developed methodology), table 3. 
Table 3. The result of comparing the availability and use of resources of physical culture and sports activities of universities for obligatory projects

\begin{tabular}{|c|c|c|c|c|c|}
\hline Obligatory project name & $\begin{array}{c}\text { University } \\
\text { No. }\end{array}$ & $\begin{array}{c}\text { Sports } \\
\text { facilities }\end{array}$ & $\begin{array}{c}\text { Sports } \\
\text { equipment }\end{array}$ & $\begin{array}{c}\text { Financial } \\
\text { resources }\end{array}$ & Staff \\
\hline $\begin{array}{c}\text { Basic professional educational programs } \\
\text { № 1-10 }\end{array}$ & 1 & -380 & -380 & 1040 & 956 \\
\hline $\begin{array}{c}\text { Basic professional educational programs № } \\
\text { 1-3 }\end{array}$ & 2 & 822 & 822 & 526 & 711 \\
\hline $\begin{array}{c}\text { Basic professional educational programs } \\
\text { № 1-15 }\end{array}$ & 3 & 3019 & 3019 & 1960 & 822 \\
\hline $\begin{array}{c}\text { Basic professional educational programs № } \\
\text { 1-45 }\end{array}$ & 4 & 602 & 602 & 7720 & 5467 \\
\hline $\begin{array}{c}\text { Basic professional educational program } \\
\text { № 1 }\end{array}$ & 5 & 789 & 789 & 528 & 347 \\
\hline $\begin{array}{c}\text { Basic professional educational program } \\
\text { № 1 }\end{array}$ & 6 & 751 & 751 & 440 & 620 \\
\hline $\begin{array}{c}\text { Basic professional educational programs № } \\
\text { 1-3 }\end{array}$ & 7 & 1671 & 1671 & 1040 & 522 \\
\hline Basic professional educational programs № \\
1-7
\end{tabular}

As can be seen from the table, for almost all participants in network interaction, there is no shortage of resources for the implementation of obligatory projects due to the fulfillment of the requirements of the main professional educational programs. At the same time, there is a shortage of space and inventory at FSBEI HE "Ural State University of Economics", so this university is forced to enter into network interaction with other universities in order to compensate for the emerging resource shortage of some of the sports facilities for the implementation of obligatory projects.

Next, we will perform the steps of stages 4 and 5 of the methodology and select participants for network interaction based on an optimization model, which includes the target function - maximizing the number of people participating in physical culture and sports activities, taking into account resource constraints: sports facilities, sports equipment, financial resources and staff. Let's consider the resource limitations of the formed matrix of the network model of physical culture and sports activity of universities of the Sverdlovsk region, table 4. 
Table 4. Resource restrictions of the formed matrix of the network model of physical culture and sports activity of universities of the Sverdlovsk region

\begin{tabular}{|c|c|c|c|c|c|c|c|c|c|c|c|c|c|c|c|}
\hline \multirow{2}{*}{ Resources } & \multirow{2}{*}{ Indicator } & \multicolumn{14}{|c|}{ University No. } \\
\hline & & 1 & 2 & 3 & 4 & 5 & 6 & 7 & 8 & 9 & 10 & 11 & 12 & 13 & 14 \\
\hline \multirow{3}{*}{$\begin{array}{l}\text { Sports } \\
\text { facilities }\end{array}$} & $\begin{array}{l}\text { Allocated } \\
\text { resources for } \\
\text { networking } \\
\text { projects }\end{array}$ & 0 & 268 & 448 & 448 & 220 & 212 & 330 & 448 & 318 & 124 & 56 & 448 & 448 & 448 \\
\hline & $\begin{array}{c}\text { Existing } \\
\text { resources }\end{array}$ & -380 & 822 & 3019 & 602 & 789 & 751 & 1671 & 838 & 1522 & 492 & 534 & 1887 & 1517 & 951 \\
\hline & $\begin{array}{c}\text { Resource } \\
\text { allocation result }\end{array}$ & -380 & 554 & 2571 & 154 & 569 & 539 & 1341 & 390 & 1204 & 368 & 478 & 1439 & 1069 & 503 \\
\hline \multirow{3}{*}{$\begin{array}{c}\text { Sports } \\
\text { equipment }\end{array}$} & $\begin{array}{c}\text { Allocated } \\
\text { resources for } \\
\text { networking } \\
\text { projects }\end{array}$ & 0 & 268 & 422 & 422 & 220 & 212 & 330 & 422 & 318 & 124 & 56 & 422 & 422 & 422 \\
\hline & $\begin{array}{l}\text { Existing } \\
\text { resources }\end{array}$ & -380 & 822 & 3019 & 602 & 789 & 751 & 1671 & 838 & 1522 & 492 & 534 & 1887 & 1517 & 951 \\
\hline & $\begin{array}{c}\text { Resource } \\
\text { allocation result }\end{array}$ & -380 & 554 & 2597 & 180 & 569 & 539 & 1341 & 416 & 1204 & 368 & 478 & 1465 & 1095 & 529 \\
\hline \multirow{3}{*}{$\begin{array}{l}\text { Financial } \\
\text { resources }\end{array}$} & $\begin{array}{c}\text { Allocated } \\
\text { resources for } \\
\text { networking } \\
\text { projects }\end{array}$ & 0 & 520 & 828 & 828 & 424 & 408 & 644 & 828 & 620 & 248 & 112 & 828 & 828 & 828 \\
\hline & $\begin{array}{c}\text { Existing } \\
\text { resources }\end{array}$ & 1040 & 526 & 1960 & 7720 & 528 & 440 & 1040 & 2280 & 1360 & 460 & 260 & 1700 & 1700 & 2280 \\
\hline & $\begin{array}{c}\text { Resource } \\
\text { allocation result }\end{array}$ & 1040 & 6 & 1132 & 6892 & 104 & 32 & 396 & 1452 & 740 & 212 & 148 & 872 & 872 & 1452 \\
\hline \multirow{3}{*}{ Staff } & $\begin{array}{l}\text { Allocated } \\
\text { resources for } \\
\text { networking } \\
\text { projects }\end{array}$ & 0 & 414 & 645 & 645 & 342 & 330 & 507 & 645 & 489 & 186 & 84 & 645 & 645 & 645 \\
\hline & $\begin{array}{l}\text { Existing } \\
\text { resources }\end{array}$ & 956 & 711 & 822 & 5467 & 347 & 620 & 522 & 1933 & 500 & 167 & 89 & 767 & 1644 & 689 \\
\hline & $\begin{array}{c}\text { Resource } \\
\text { allocation result }\end{array}$ & 956 & 297 & 177 & 4822 & 5 & 290 & 15 & 1288 & 11 & -19 & 5 & 122 & 999 & 44 \\
\hline
\end{tabular}

As the analysis of the resources allocation of participants in network interaction shows (Table 4), the expansion of participation in projects of physical culture and sports activities of universities is mainly due to the provision of projects with the necessary additional personnel, and also, which turned out to be most typical for ANO HE "Humanitarian University" and FSBEI HE "Ural State Conservatory named after M.P. Mussorgsky", restrictions with financial support of projects were revealed.

The results obtained allow us to speak about the effectiveness of using the project approach in the strategy of network management of physical culture and sports activities of universities, since the number of participants involved can be significantly increased from 31 917 to 41151 people with more effective use of existing resources. Further research can be aimed at a more detailed description of the project profiles of universities - participants in network interaction and analysis of the balance of the network strategy. 


\section{Conclusions}

The results of the study allow us to confirm the provisions of the network theory and the resource approach in the strategic management of organizations regarding the achievement of higher indicators with the effective use of opportunities for the involvement and redistribution of resources within the network. The data obtained can be used within the framework of territorial locations to increase the effectiveness of the use of both sports infrastructure facilities and, in general, for social facilities.

\section{References}

1. A.A. Gresko, M. S. Rakhmanova, K. S. Solodukhin, Modern problems of science and education, 4 (2012)

2. K.S. Elenev, Yu.Ya. Eleneva, Modern problems of science and education, 1 (2013)

3. V.N. Lupanov, University Management: Practice and Analysis, 2 (2009)

4. A. Plakhin, M. Kocheryan, T. Volovik, Revista inclusions, 3 (2020)

5. M. Castells, Formation of a society of network structures (1999)

6. R Keast. et al. Network structures: Working differently and changing expectations, Public administration review, 3 (2004)

7. W. Mastenbrook, Management of conflict situations and organization development: Translated from English (1996)

8. J. Webster, The Journal of Strategic Information Systems, 1 (1995) 